\title{
EFEKTIVITAS PEMBELAJARAN DARING DI MASA PANDEMI MENUJU ERA NEW NORMAL
}

\author{
Mastiah \\ Program Studi Pendidikan Ilmu Pengetahuan Sosial, FKIP Universitas Lambung Mangkurat \\ mastiahasti934@gmail.com
}

\begin{abstract}
ABSTRAK
Pendidikan merupakan salah satu hal terpenting dalam sebuah negara. Kala pandemi proses pendidikan tetap perlu dijalankan, karena mengingat akan pentingnya pendidikan bagi Indonesia. Upaya yang diambil oleh pemerintah saat ini yaitu kebijakan New Normal. Dalam kebijakan pendidikan pemerintah masih menerapkan pembelajaran daring (online) kepada para peserta didik, karena di era New Normal masih belum memungkinkan untuk melakukan pembelajaran tatap muka secara langsung mengingat jumlah penyebaran virus Covid-19 kian bertambah setiap harinya. Maka dari itu pembelajaran daring (online) merupakan titik tengah yang dapat diambil oleh pemerintah dalam bidang pendidikan dikala pandemi saat ini.
\end{abstract}

Kata Kunci: Era New Normal, Pendidikan, Kebijakan.

\section{PENDAHULUAN}

Pandemi corona bukan hanya terjadi di Indonesia, tetapi seluruh dunia telah terdampak wabah tersebut. Indonesia menyatakan tertular wabah ini pada bulan Maret 2020 ketika dua WNI terdeteksi positif corona, yang kemudian berkembang sangat pesat hingga menyebar ke 34 provinsi di Indonesia. Pada tanggal 11 Maret 2020 WHO menetapkan wabah ini sebagai pandemik global. Secara global korban meninggal telah mencapai 316.860 orang dan di Indonesia telah menembus hingga angka 1.192 orang (data per 18 Mei 2020). (Syaharuddin, S, 2020). Pada saat ini secara global jumlah korban meninggal akibat virus Covid-19 mencapai 629,339 juta jiwa. Sedangkan jumlah kasus Covid-19 di Indonesia mencapai 93.657 jiwa. (Data Per 23 Juli 2020).

Pada saat ini pemerintah ikut andil dalam pencegahan penyebaran virus Covid-19. Pemerintah berusaha membantu masyarakat di masa pandemi dengan memberikan Bantuan Langsung Tunai (BLT) kepada masyarakat yang berhak menerima bantuan tersebut. Selain itu pemerintah juga memberikan subsidi listrik serta memotong pembayaran pajak selama masa 
pandemi. Hal ini dilakukan dengan harapan agar dapat mengurangi beban masyarakat akibat dari wabah virus Covid-19. Pemerintah mengeluarkan kebijakan dalam menangani berbagai permasalahan, yaitu diberlakukannya lock down di setiap wilayah agar dapat membantu memutuskan rantai penyebaran Covid-19. Masih belum efektif dengan kebijakan lock down, pemerintah menerapkan Pembatasan Sosial Berskala Besar (PSSB), tetapi hal ini juga tidak dapat berlangsung lama, mengingat perekonomian rakyat Indonesia yang semakin terpuruk karena tidak dapat berkerja untuk memenuhi kebutuhan mereka namun hal ini segara diatasi oleh pemerintah dikala menuju era new normal.

Dampak yang ditimbulkan wabah corona sangat besar. Terkhusus yang terjadi di Indonesia, salah satu dampaknya yaitu dalam bidang pendidikan, pada era new normal dalam dunia pendidikan sangat berpengaruh besar. Maka dari itu pemerintah mengeluarkan kebijakan Pembelajaran Jarak Jauh (PJJ) secara daring, yang secara tidak langsung mengurangi peran guru sebagai pendidik. Guru tidak bisa memberikan pembelajaran secara langsung serta tidak bisa mengontol peserta didiknya secara langsung, hingga peran pendidikan sebagai pembetuk karakter peserta didik tidak dapat diperoleh secara maksimal. Namun dibalik semua itu pembelajaran daring menjadi solusi bagi sebagaian masyarakat. Hal ini dilakukan agar menghindari bertambahnya rantai penyebaran Covid-19 dalam lingkungan pendidikan.

\section{PEMBAHASAN}

Coronavirus Disease 2019 (COVID-19) merupakan penyakit menular terbaru yang masih belum di temukan vaksinisasinya hingga saat ini. Penyebaran Covid-19 juga sangat cepat ke berbagai belahan dunia hanya dengan waktu beberapa bulan saja virus ini sudah menyebar dengan cepat di Indonesia. Karena penyebaran yang bisa dilakukan lewat sentuhan dan sebagainya. Bahkan ada orang yang tanpa memiliki gejala terjangkit virus, sehingga hal inilah yang berpotensi besar menyebarkan Covid-19 kepada orang lain. Maka dari itu semakin hari semakin banyak masyarakat yang terpapar virus Covid-19, bahkan hingga sekarang mencapai ribuan kasus perharinya. Hal ini juga disebabkan dari tindakan masyarakat yang masih enggan menerapkan protokol kesehatan yang sudah diberlakuan pemerintah. Bahkan tanpa disadari oleh orang yang terenfeksi bahwa ia yang menyebarkan virus kepada orang lain, karena kebanyakan masyarakat yang usia produktif tidak menimbulkan gejala jika ia terpapar virus Covid-19. 
Pemerintah sudah mengeluarkan berbagai kebijakan untuk menekan jumlah penyebaran virus Covid-19 ini yaitu yang diawali dengan diberlakukannya lock down di setiap daerah dengan harapan agar bisa menekan jumlah penyebaran virus Covid-19. Namun kenyataannya tidak demikian kasus penyebaran Covid-19 semakin bertambah setiap harinya dan bahkan membuat perekonomian masyarakat Indonesia semakin terpuruk, jika terus di biarkan demikian maka Indonesia akan mengalami krisis ekonomi yang sangat besar. Walaupun pemerintah sudah memberikan bantuan berupa sembako, Bantuan Langsung Tunai (BLT), memberikan subsidi listrik, serta pemotongan biaya pajak kepada masyarakat. Tetapi hal ini cuma sedikit membantu sebagian masyarakat Indonesia, serta dirasa kurang efektif dalam menangani permasalahan akibat pandemi.

Pemerintah kemudian mengeluarkan kebijakan New Normal untuk mengatasi berbagai permasalahan ekonomi yang terjadi di Indonesia, sehingga masyarakat bisa kembali bekerja untuk memenuhi kebutuhan hidup mereka. Hal ini dapat dilakukan dengan syarat masyarakat wajib menerapkan protokol kesehatan yang diberlakukan oleh pemerintah, seperti selalu menggunakan masker saat berada di luar rumah, selalu mencuci tangan setelah menyetuh benda yang ada di luar, selalu menjaga jarak (physical distancing) serta menghindari kerumunan. Kebijakan ini diberlakukan agar perekonomian masyarakat Indonesia bisa kembali membaik dan diharapkan penerapan protokol kesehatan ini juga akan menekan jumlah penyebaran Virus Covid-19 yang ada di Indonesia. (Syaharuddin, S, 2020).

Begitu pula halnya kebijakan dalam bidang pendidikan pemerintah memberlakukan pembelajaran daring (online) kepada para peserta didik Sekolah Dasar, Sekolah Menengah maupun Perguruan Tinggi. Upaya ini dilakukan agar meminimalisir penyebaran Covid-19 di lingkungan pendidikan, sehingga bisa memutus mata rantai penyebaran virus corona. Pembelajaran abad-21 mengajarkan kita untuk memanfaatkan seluruh kemajuan teknologi yang ada untuk menunjang proses pembelajaran, apalagi dikala pandemi. Pemberlakukan kebijakan new normal merupakan solusi yang dapat berikan oleh pemerintah baik untuk kepentingan pendidikan maupun kepentingan ekonomi masyarakat Indonesia. Pembelajaran daring ini dilakukan untuk memenuhi standar pendidikan dengan memanfaatkan Teknologi dan Komunikasi agar pembelajaran dapat terlaksanakan di era pandemi. (Mutiani, M., \& Faisal, M, 2019). 
Pembelajaran daring ini adalah upaya yang dapat di lakukan pemerintah agar pembelajaran tetap berlangsung walaupun tidak secara tatap muka dengan memanfatkan kemajuan teknologi. Memang pembelajaran daring ini tidak seefektif saat melakukan pembelajaran secara tatap muka langsung, karena guru tidak bisa mengontrol peserta didiknya secara langsung. Begitu pula halnya dengan peserta didik ia tidak bisa leluasa menanyakan berbagai hal kepada gurunya karena berbagai kendala, seperti keterbatasan waktu, jaringan seluler dan sebagainya. Meskipun demikan para pendidik tetap bisa menanamkan nilai-nilai karakter yang baik kepada peserta didiknya walaupun hanya melalui pembelajaran daring. (Subiyakto, B., \& Mutiani, M, 2019)

Kebijakan pembelajaran daring (online) ini diharapkan agar peserta didik tetap bisa melakukan pembelajaran meskipun dimasa pandemi guna membentuk karakter peserta didik yang kritis dalam berpikir dan bertanggung jawab dalam berbagai hal, serta tanggap dalam menyipaki berbagai masalah yang ada dilingkungan sosialnya. Apalagi saat pandemi seperti ini diharapkan peserta didik tanggap dalam menangggapi berbagai kebijakan yang diterapkan oleh pemerintah ditengah-tengah masyarakat. (Janah, W. A., Abbas, E. W., \& Mutiani, M, 2020).

Dalam era pandemi kurikulum pendidikan tetap berlangsung dengan semestinya, namun bedanya hanya melalui pembelajaran daring tidak tatap muka secara langsung. Dengan adanya handphone sebagai media Pembelajaran Jarak Jauh (PJJ) di manfaatkan untuk menunjang proses pembelajaran. (Susanto, H., \& Akmal, H, 2019). Begitu pula halnya tugas yang semestinya dilakukan dengan penelitian atau sebagainya dialihkan menjadi serba online, sehingga mencari berbagai referensi pembelajaran pun dilakukan secara online. Hal ini dilakukan agar tujuan pendidikan tetap bisa terlaksana walaupun ditengah pandemi, karena jika tidak dilakukan demikian bagaimana kita bisa mencetak generasi yang pandai menyikapi segala hal, berpikir kritis dan bertanggung jawab jika masalah pandemi ini dijadikan alasan untuk tidak melakukan pembelajaran. (Subiyakto, B., \& Abbas, E. W, 2020). Telah kita ketahui bersama jika pembelajaran di lakukan secara langsung di seluruh wilayah maka besar kemungkinan penambahan jumlah kasus Covid-19 ini kian merebak. Maka dari itu pemberlakuan pembelajaran daring ini sebagai solusi yang bisa dilakukan oleh pemerintah menuju new normal.

Kita bisa menggunakan berbagai aplikasi di telepon pintar untuk menunjang proses pembelajaran, seperti Google Classroom, Edmoto, Google Meet, Zoom dan lain sebagainya. Berbagai aplikasi ini dapat dimanfaatkan untuk proses interaksi antara peserta didik dan 
pengajar melalui forum diskusi, terkait dengan berbagai materinya yang sedang diajarkan oleh pendidiknya agar dapat berjalannya pembelajaran secara interaktif.

Teknologi pada masa pandemi sekaligus bisa gunakan sebagai media pembelajaran bagi guru maupun peserta didik dalam proses pembelajaran, karena dari teknologi inilah segala materi pelajaran dan berbagai informasi tentang pendidikan diperoleh peserta didik. Segala macam materi yang diperoleh bisa dijadikan sebagai sumber belajar berupa buku elektronik, media cetak maupun dari lingkungan sosialnya. Sumber belajar merupakan hal yang digunakan untuk menunjang proses pembelajaran sesuai dengan Kompetensi Inti (KI) dan Kompetensi Dasar (KD) yang telah ditetapkan. (Wahyuningsih, S., Abbas, E. W., \& Mutiani, M, 2020).

Peran orang tua juga tentunya sangat diperlukan pada saat pembelajaran daring. Mengapa demikian? Karena saat pembelajaran daring seorang pendidik tidak bisa mengawasi peserta didiknya secara langsung. Maka orang tuanyalah yang berperan sebagai guru di kala pembelajaran. Orang tua bisa selalu memotivasi anaknya agar tidak bosan saat melakukan pembelajaran dirumah, karena mereka tidak bisa bertemu dan bermain bersama temantemannya disekolah. Selain itu orang tua juga bisa memahamkan pembelajaran kepada anaknya agar mereka lebih paham dan mudah dalam mengaplikasikannya. Dari sinilah orang tua bisa selalu mengontrol perkembangan anak dalam pembelajaran saat dirumah.

Pembelajaran menulis juga bisa kita lakukan saat pendami seperti ini. Menulis bukan menambah masalah dan bukan juga sebuah tantangan justru dengan menulis kita bisa menuangkan berbagai ide dan pengetahuan kita melalui tulisan. (Abbas, E. W, 2020). Karena di kala pandemi seperti ini kita jangan terlalu membebankan diri dengan berbagai pikiran buruk yang mungkin terjadi, lebih baik kita gunakan waktu yang kita miliki untuk hal yang bermanfaat agar bisa mengusir rasa khawatir terhadap pengaruh dari pandemi ini. Kita bisa manfaatkan waktu luang dengan menyalurkan rasa khawtir dan gelisah melalui sebuah tulisan hal ini lebih bermanfaat dan menjadi solusi agar dapat menenangkan perasaan gundah yang ada dalam diri, karena melalui tulisan tersebutlah perasaan itu akan tersalurkan. (WARMANSYAH ABBAS, E. R. S. I. S, 2020).

Kala pandemi saat ini berbagai teknologi dapat kita gunakan seperti yang terdapat pada Universitas Lambung Mangkurat, mahasiswa dapat menggunakan E-Learning untuk menunjang proses pembelajaran. Dalam E-Learning juga terdapat forum diskusi, forum pengupload tugas, 
materi pelajaran dan sebagainya untuk menunjang proses pembelajaran mahasiswanya saat pembelajaran daring (online). (ABBAS, E. W, 2019).

Kala pandemi tidak menutup kemungkinan bahwa kita masih bisa menggunakan sumber pembelajaran yang berbasis kearifan lokal misalnya pada pembelajaran IPS di Sekolah Menengah Pertama bisa kita jelaskan pada peserta didik tentang manfaat dan fungsi dari kerajinan anyaman purun yang ada di daerah Kalimantan Selatan untuk kita lestarikan sebagai para penerus bangsa. Walaupun dimasa pandemi pendidik tetap harus menggunakan sumber pembelajaran yang berbasis kearifan lokal. (Lestari, J. A., Abbas, E. W., \& Mutiani, M, 2020).

Memasukkan materi berbasis kearifan lokal dalam pembelajaran daring adalah suatu ide yang positif karena dari sana guru dapat memudahkan peserta didik memahami pembelajaran. Misalnya mengambil contoh yang bersinggungan langsung dengan lingkungan sosialnya. (Abbas, E. W., Handy, M. R. N., Shaleh, R. M., \& Hadi, N. T. F. W, 2020). Disini kita ambil contoh pasar terapung yang ada di Banjarmasin, di sana berbagai interaksi terjadi antara penjual dan pembeli menggunakan perahu (jukung). (Yuniarti, D., Subiyakto, B., \& Putra, M. A. H, 2020). Memanfaatkan Pasar Terapung sebagai sumber belajar IPS merupakan salah satu inovasi dalam sebuah pembelajaran. (Abbas, E. W., \& Rajiani, I, 2019). Selain hal itu kita juga bisa mengenalkan fungsi sungai yang ada di Banjarmasin sebagai tempat mata pencaharian masyarakat, yang dimana disana dilakukan berbagai aktifitas seperti berdagang, alat transportasi klotok untuk wisata dan sebagainya. (Syaharuddin, S., Susanto, H., \& Putra, M. A. H, 2020). Selain Pasar Terapung, Sasaringan juga merupakan suatu kearifan lokal yang ada di Kalimantan selatan yang juga bisa dimasukkan sebagai sumber pelajaran IPS dalam pembelajaran daring kala pandemi. (Jumriani, J., Subiyakto, B., \& Syaharuddin, S, 2019). Hal ini dilakukan agar pembelajaran tidak membosankan dan lebih bermakna. (Syaharuddin, S., Rahman, A. M., \& Fitriyani, R, 2020).

Bukan hanya kearifan lokal yang bisa kita jadikan sebagai sumber belajar tetapi tempat wisata sekalipun bisa kita manfaatkan sebagai sumber pembalajaran dikala pandemi. Tidak bisa berwisata secara langsung dengan leluasa seperti sebelum terjadi pandemi, maka kita bisa jadikan tempat wisata sebagai sumber belajar dalam pembelajaran daring. Seperti halnya Patung Maskot Bekantan yang dijadikan sebagai objek wisata yang dibangun di tepi sungai dan mencerminkan identitas fauna yang ada di Kalimantan Selatan. Dari sana kita kenalkan bahwa Kalimantan Selatan memiliki fauna langka yang harus dilindungi. (Ajidayanti, A., \& Abbas, E. 
W, 2019). Selain tempat wisata Maskot Bekatan, kita juga bisa mengambil contoh Amanah Borneo Park, karena dari sana bisa mengajarkan kepada peserta didik bagaimana berinteraksi dengan alam dan menjaga linkungan agar tetap lestari. Walaupun hanya dengan melakukan pembelajaran daring hal seperti ini tetap perlu kita ajarkan kepada peserta didik, agar terbentuk peserta didik yang peka terhadap lingkungan, menjaga kebersihan serta kelestarian yang ada dilingkungannya. (Noerkhalishah, N., Abbas, E. W., \& Permatasari, M. A, 2020).

Sesuai dengan tujuan kurikulum 2013 yang di tuntut untuk menyajikan pengetahun sosial budaya yang menarik dan berada pada daerah tempat tinggal peserta didik, kita bisa membuat mereka menjadi anak yang berpikir kreatif, kritis dalam segala hal, pandai dalam bertindak, serta cerdas dalam menyikapi berbagai hal sehingga akan dengan mudah terwujudnya tujuan dari pembelajaran.

\section{SIMPULAN}

New normal merupakan kebijakan yang dilakukan pemerintah untuk mengatasi berbagai permasalahan yang terjadi di kala pandemi, khususnya dalam bidang pendidikan. Setelah diberlakukannya new normal pembelajaran tetap dilakukan secara daring dengan tujuan agar bisa memutus mata rantai penyebaran Covid-19 dalam lingkungan pendidikan.

Pembelajaran daring tidak menjadi penghalang dalam proses pembelajaran dikala pandemi. Karena hal ini merupakan upaya yang telah dilakukan oleh pemerintah agar proses pembelajaran tetap terlaksana meskipun secara online. Tenaga pendidik tetap perlu memberikan pembelajaran yang sesuai kurikulum, sehingga dapat terwujudnya tujuan pembelajaran. Membuat peserta didik pandai dalam menanggapi segala hal, bertanggung jawab dan mempunyai pemikiran yang kritis.

\section{DAFTAR PUSTAKA}

\section{ABBAS, E. W. (2019). MANAGING INFORMATION SYSTEMS BY INTEGRATING}

Abbas, E. W. (2020). Menulis Artikel Jurnal. Menulis Artikel Jurnal.

Abbas, E. W., \& Rajiani, I. (2019). Social Life of Santri in the Bank of Martapur River as the Learning Sources of Social Science Studies. Social Life of Santri in the Bank of Martapur River as the Learning Sources of Social Science Studies. 
Abbas, E. W., Handy, M. R. N., Shaleh, R. M., \& Hadi, N. T. F. W. (2020). Ecotourism of Martapura River Banjarmasin as a Learning Resources on Social Studies. The Innovation of Social Studies Journal, 1(2), 111-119.

Ajidayanti, A., \& Abbas, E. W. (2019). Utilization of Tourism Bekantan Mascot as a Learning Resource On Social Studies. The Innovation of Social Studies Journal, 1(1), 78-86. DARING. INFORMATION SYSTEMS SUCCESS MODEL AND THE UNIFIED THEORY

Janah, W. A., Abbas, E. W., \& Mutiani, M. (2020). The Contribution of Leadership Value of Nadjmi Adhani as a Learning Resources on Social Studies. The Innovation of Social Studies Journal, 1(2), 188-196.

Jumriani, J., Subiyakto, B., \& Syaharuddin, S. (2019). Social Interaction Sasirangan Traders Village in The City of Banjarmasin as a Learning Resources on Social Studies. The Innovation of Social Studies Journal, 1(1), 65-77.

Lestari, J. A., Abbas, E. W., \& Mutiani, M. (2020). Production Activities of Kampung Purun Banjarbaru as a Learning Resource on Social Studies. The Innovation of Social Studies Journal, 1(2), 139-149. Management Studies.

Mutiani, M., \& Faisal, M. (2019). Urgency of The 21st Century Skills and Social Capital in Social Studies. The Innovation of Social Studies Journal, 1(1), 1-11.

Noerkhalishah, N., Abbas, E. W., \& Permatasari, M. A. (2020). The Utilization of Tourism Education Packages in Amanah Borneo Park as a Learning Resources on Social Studies. The Innovation of Social Studies Journal, 1(2), 158-168.

OF ACCEPTANCE AND USAGE OF TECHNOLOGY. Polish Journal of

Subiyakto, B., \& Abbas, E. W. (2020). Strategi Pembelajaran IPS: Konsep dan Aplikasi.

Subiyakto, B., \& Mutiani, M. (2019). Internalisasi nilai pendidikan melalui aktivitas masyarakat sebagai sumber belajar ilmu pengetahuan sosial. Khazanah: Jurnal Studi Islam dan Humaniora, 17(1), 137-166.

Susanto, H., \& Akmal, H. (2019). Media Pembelajaran Sejarah Era Teknologi Informasi (Konsep Dasar, Prinsi Aplikatif, dan Perancangannya).

Syaharuddin, S. (2020). Menimbang Peran Teknologi dan Guru dalam Pembelajaran di Era COVID-19. Menimbang Peran Teknologi dan Guru dalam Pembelajaran di Era COVID-19.

Syaharuddin, S. (2020). PEMBELAJARAN MASA PANDEMI: DARI KONVENSIONAL KE DARING. PEMBELAJARAN MASA PANDEMI: DARI KONVENSIONAL KE

Syaharuddin, S., Rahman, A. M., \& Fitriyani, R. (2020). Utilization Of Social Community as Learning Resources On Social Studies. The Kalimantan Social Studies Journal, 1 (1), $18-24$.

Syaharuddin, S., Susanto, H., \& Putra, M. A. H. (2020). Portrait of Community Economic Activities in The River as a Learning Resources on Social Studies With Local CultureBased. The Innovation of Social Studies Journal, 1(2), 178-187. 
Wahyuningsih, S., Abbas, E. W., \& Mutiani, M. (2020). Implementation of Leadership Value of Rudy Resnawan as a Learning Resources on Social Studies. The Innovation of Social Studies Journal, 1(2), 169-177.

WARMANSYAH ABBAS, E. R. S. I. S. (2020). Menulis di Era Covid-19: Memanage Trauma Psikologis Menghindari Psikosomatis. Menulis di Era Covid-19: Memanage Trauma Psikologis Menghindari Psikosomatis.

Yuniarti, D., Subiyakto, B., \& Putra, M. A. H. (2020). Economic Activities in Kuin Floating Market as a Learning Resource on Social Studies. The Kalimantan Social Studies Journal, 1(2), 130-140. 